\title{
THE TECHNIQUES OF TRANSLATION OF CULTURE-BOUND TERMS FROM RUSSIAN INTO ENGLISH IN LITERARY WORKS
}

\author{
Julia Ilina ${ }^{1}$,Elena Mozzhegorova²
}

\begin{abstract}
The article is devoted to the problem of translation of culture specific words from Russian into English in literary works. Translation of cultural concepts is an important aspect of preserving cultural identity of a literary work. The main purpose of the study is to analyze possible translation strategies of culture-bound elements in domestic and foreign theory and to identify the actual patterns of translation of these elements in practice. The material for the practical analysis was taken from the novel Zuleikha by Guzel Yakhina and its translation into English.
\end{abstract}

Key words: culture-bound terms, national-specific vocabulary, literary translation, strategies of translation, cultural equivalent, transliteration.

doi: http://doi.org/10.15350/L_2/5/37

The texts of fiction refer to a special group of texts because of their characteristic features and functions. Any literary text has a national cultural code, the translation of which represents a certain problem and must be approached creatively. The creative potential of a translator is the key to the success of a literary translation. The translator in some way creates a new literary work, trying to see it with his or her own eyes and translate not only lexical items, but also the author's thoughts, the facts, the state of the characters, their inner world and etc. [1, p. 25].

Cultural concepts in a literary work make a translation process a challenging one. In modern dictionaries any subject of material culture is considered to be a culture-bound term. Examples include the structure of the country, the culture and history of its people, etc. According to Russian linguists these are objects and phenomena that reflect the peculiarities of life and way of life of a certain people. These terms in fact are not peculiar to the practical experience of people speaking another language, so the words denoting them belong to the class of non-equivalent vocabulary and therefore require a special translation approach [2, p. 239].

According to G. Chernov and V. Komissarov culture-bound terms are non-equivalent vocabulary, they denote special concepts and national phenomena. They can be even referred to neologisms, as well as words used to describe obscure names and names with occasional correspondence [3, p. 130], [4, p. 148].

S. Vlakhov and S. Florin give the definition of culture-specific elements as "words and/or phrases denoting objects characteristic of the life of one people and alien to another. Such words and phrases are carriers of national nuances, which does not allow to find an adequate equivalent in other languages" [5].

1Julia Ilina, Student of Faculty of Foreign Languages, I. Yakovlev Chuvash State Pedagogical University, Russia.

${ }^{2}$ Elena Mozzhegorova, Candidate of Pedagogic Sciences, Associate Professor, I. Yakovlev Chuvash State Pedagogical University, Russia. 
It should be noted that the "translation of a culture-bound term is based on the contrast. It is an object, concept or phenomenon represented in the language and culture of one people, which has no analogues in another culture, but at the same time there are no words and phrases that can not be translated into another language" [6, p. 182].

The analysis of different translation techniques for culture-bound terms such as calque, transference, modulation and some others proves the complexity of the translation process. Different academicians offer different procedures for translating culturespecific terms. Some of them suggest creating a new word or explaining the meaning of the source language expression. At the same time the translator is free to decide whether to preserve the source language term or to choose a word in the target language.

E. Nida and C. Taber thoroughly analysed the problem of translation of cultural concepts and provided classifications of cultural terms according to five major fields: ecology, material culture, social culture, ideological culture, linguistic culture [7].

M. Harvey defines culture-bound terms as the terms which "refer to concepts, institutions and personnel which are specific to the source language culture" [8]. Consequently, four main techniques are offered for translation of these terms. The first one is functional equivalence, which implies using a referent in the target culture the function of which is similar to that of the source language referent. The second technique is the formal equivalence or 'linguistic equivalence', which is a word-for-word translation. The third one is transcription or borrowing, which is reproducing or transliterating the original term. If the term is understandable or is explained in the context, it may be used alone, or followed by transcription with the explanation or a note of a translator. The fourth technique is a descriptive translation, when the translator uses a generic term to convey the meaning [8].

P. Newmark, a prominent translation scholar, writes about the following translation procedures:

- transference, which is the process of transferring a source language word to a target language text;

- naturalization, technique which consists of adapting the source language word first to the pronunciation, then to the morphology of the target language;

- cultural equivalent, which is replacing a cultural word in the source culture with a target language one;

- functional equivalent, requiring the use of a culture-neutral word;

- descriptive equivalent, which supposes that the meaning of the culture-bound term is explained in several words [9, p. 114].

So, as far as the practical choices concerned, translators of literary texts face two difficulties in translating culture-bound terms. On the one hand, it is impossible to select an adequate equivalent on the semantic level, and on the other hand there is a need to preserve the national and historical and cultural nuances of the language.

In the practical part of our research, we grouped the culture-bound terms in the novel Zuleikha, analyzed their translation into English and studied the techniques used by the translator.

Guzel Yakhina is a bright name in the modern Russian literature. She became famous in 2015 when her first novel Zuleikha was published. G. Yakhina tells about the life of a Tatar woman in the first half of the XX century that is why the text of the novel is riddled with different cultural vocabulary of the life, traditions and social customs of the Tatar people. At the same time this novel is not just the story of a Tatar woman; it is a valuable collection of the cultural heritage of the Tatar people, the quintessence of the pain of people who tried to survive in the period of dekulakization (defarming). The novel was translated into English in 2019. 
We used the classification of A. Fedorov to select the practical material for the study. According to him, the first group of cultural vocabulary are non-equivalent nationally labeled units, the so-called 'ethnographisms', which as a rule, represent everyday vocabulary [6, p. 342].

So, we included the following culture-bound terms from the novel into the first group: a) terms that are used in everyday life and housekeeping: kamcha (whip, lash) 'The whip is strong and braided' [10, p. 48], kaplau (veil) 'Frightened, Zuleikha leans against the trunks stacked up by the window, hastily straightening the lace kaplau with her hand' [10, p. 51], kashaga (the valance around the edge beams in the house) 'A cobweb-thin silk valance on the beams under the ceiling borders the room like an expensive frame' [10, p. 22], kishte (shelf near the ceiling for storing bedding) 'Takes her husband's pillows down from the high storage shelf and plumps them' [10, p. 19], leguen (wash basin) 'Several wooden wheels, a hollowed-out trough, and a copper basin with shiny curves' [10, p. 40], leuke (shelf in the bath) 'She climbs up on the highest steaming shelf' [10, p. 26], syake (the wide bench) 'Sets a place for Murtaza at the wide sleeping bench, tossing some food on it' [10, $\mathrm{p}$. 19], taban (table, eating) 'Sets a place for Murtaza at the wide sleeping bench, tossing some food on it [10, p. 19]', tastymal (long embroidered towel) '...and hanging on the walls are smart, long, red and green embroidered towels' [10, p. 22], charshau (curtain) 'Scurry soundlessly behind the printed cotton curtain separating the women's quarters of the log house from the men's' [10, p. 4], chybyldyk (curtain) '...to the small part of the sleeping bench that's separated from the men's quarters by a drape' [10, p. 20];

b) clothes and shoes: kulmek (dress, shirt) 'She lowers her nightshirt over it and puts on a smock and baggy wide pants' [10, p. 10], kota (short home boots) 'She wouldn't be able to make her way silently in her little felt boots' [10, p. 3], malahay (shaggy fur hat) 'He takes off his shaggy fur hat' [10, p. 14] , chyba (upper demi-season clothing) '...who's sitting between the humps and wearing a colourful quilted robe' [10, p. 124], tyubeteyka (national headdress) '...after placing a green velvet embroidered skullcap on his head' [10, p. 95];

c) food: kosh-tele (crumbly light pastries) 'She later took nuts in honey, crumbly light pastries, and dried berries' [10, p. 19], kyzylyk (horse sausage) 'Zuleikha's nostrils draw in the sharp, salty aroma of kyzyly $\boldsymbol{k}^{\prime}[10$, p. 41], etc.

The second group consists of vocabulary marking mythological representations and beliefs of the people. For example, these are mythological and folklore characters of the Tatar people: azhdakha (dragon) '...about fire-brearhing azhdakha dragons that hide in the bottom of wells' [10, p. 383], alabasty (female demonic character in the mythology) '...scarier than a demonic alabasty woman...' [10, p. 40], basu kapka iyase (the spirit of the outskirts) 'Here, under the fence of the last house is the home of basu kapka iyase' [10, p. 18], bichura (brownie, low spirit) 'For example, the bichura living in the entrance hall isn't picky' [10, p. 18], dev (evil spirit, anthropomorphic giant) '...as gluttonous as a giant evil dev...' [10, p. 40], zhalmavyz (the mythological giant woman, a glutton and a cannibal) '...and the gluttonous giantess, Zhalmavyz' [10, p. 391], zirat iyase (graveyard spirit) '...which was to request that the zirat iyase - the cemetery spirit - look after her daughters' [10, p. 18], iyase (house spirit) 'She hasn't been able to discover if this train car has its own iyase' [10, p. 161], peri (a mythological spirit in the image of a girl) '...crafty and beautiful women called peri' [10, p. 391], su-anasy (water spirit) '...about a certain unkempt water spirit called Su-Anasy' [10, p. 383], Ubyrly Karchyk (bloodthirsty demonic old woman, witch) 'Ubyrly Karchyk - the Vampire Hag' [10, p. 5], fereshte (the angel) '...but three fiery angels will fly here for you' [10, p. 29], shurale (the spirit of the forest, the Goblin) '...about shurales, who tickle tardy tardy forest wayfarers to death' [10, 383].

The third group are the national traditions and customs of the Tatar people: kalym (bride price) 'Malicious gossips joke that he hasn't ever in his life had the honor of saving up bride-money' [10, p. 43], keresh (Tatar national struggle) 'Murtaza is squeezing his 
mother's body tightly, grasping, as a wrestler embraces an opponent' [10, p. 49], Kurban (Muslim feast of sacrifice) 'Husbands allowed women into the mosque reluctantly, only for big holidays, at Eid al-Fitr and Eid al-Adha' [10, p. 94], kyz-kuu (horse game) 'I had the most beautiful pinafore in Yulbash for kyz-kuu' [10, p. 47], tuy (holiday, wedding) 'He will propose initiatives and rename the pagan holiday Sabantuy' [10, p. 100] , Uraza (Muslim holiday in honor of the end of the fast of Uraz) 'Husbands allowed women into the mosque reluctantly, only for big holidays, at Eid al-Fitr and Eid al-Adha' [10, p. 94].

The fourth group consists of nominations representing the objects and cultural concepts of religious worship: lyaukhe (a wall mat with a saying from the Koran) 'Finally he catches the blade of his bayonet on a tapestry embroidered with a saying from Koran that hangs high over the entrance' [10, p. 75], mihrab (prayer niche in the mosque) 'He's continuing to pray, sitting facing the prayer niche' [10, p. 95].

The nominations used to designate persons of a certain religious and/or social status should be pointed out separately: mullah (Minister of religious worship among Muslims) 'I saw the mullah' [10, p. 95], abystay (wife of a spiritual person) 'The holy man's wife told me about it' [10, p. 13].

The fifth group includes Tatar names and nicknames: zhebegyan tavyk (wet hen) 'It was the Vampire Hag who first called her zhebegyan tavyk - pitiful hen' [10, p. 5], urman (mixed forest) 'People say it's possible to go to the lands of Mari people by walking through the urman, away from the sun for many days in a row' [10, p. 12], Kyubelek (cow nickname, which means a butterfly) 'Murtaza and Kyubelek are standing in the middle of the yard' [10, p. 55], Ulym (son) 'Murtaza, ulym, don't beat her, have pity' [10, p. 31], Eni (mother) 'What happened, Eni?' [10, p. 30], tashkil (the system of superscript and subscript characters in the Arabic language) '...her fingers melting the ice in the shallow dimples of the tashkil over the long wave of letters' [10, p.59], aga (respectful address to older man) 'you don't know where they're taking us, do you' [10,129], fekhishe (prostitute) 'Listen here, you slut' [10, p. 460], tur (the honourable corner in the hut) 'The old woman sits enthroned in the corner of honor, the tur...' [10, p. 22].

As we can see from the examples, G. Yakhina in her novel introduces a lot of cultural elements, which are provided by the description the first time they appear in the story. So the translator Lisa C. Hayden preserved the author's style and followed her pattern of narration and used different techniques to transfer these elements into the English language such as transliteration, functional equivalent, linguistic equivalent and descriptive translation, which helped to preserve the national and cultural nuances of Tatar customs and create a vivid picture of their way of life.

\section{References}

[1] Kazakova T.A. Hudozhestvennyj perevod. Uchebnoe posobie. Sankt-Peterburgskij institut vneshneekonomicheskih svyazej, ekonomiki i prava. 2002. (in Russian)

[2] Barkhudarov L.S. Yazyk i perevod (Voprosy obshchej i chastnoj teorii perevoda). Moscow: Mezhdunar. otnosheniya. 1975. (in Russian)

[3] Chernov G.V. Osnovy sinkhronnogo perevoda. Moscow: Vyshaya shkola. 1987. (in Russian)

[4] Komissarov V.N. Teoriya perevoda (lingvisticheskie aspekty). Moscow: Vyshaya shkola. 1990. (in Russian)

[5] Vlakhov, S. and Florin, S. Neperovodimoe v perevode. Moscow: R.Valent. 2009. (in Russian)

[6] Fedorov A.V. Osnovy obshchej teorii perevoda (lingvisticheskie problemy). Dlya institutov i fakultetov inostr. yazykov. Saint-Petersburg: Filologia tri. 2002. (in Russian)

[7] Nida, E.A., \& Taber, C.R. (1982). The theory and practice of translation. Leiden: E.J. Brill.

[8] Harvey, M. (2000). A beginner's course in legal translation: the case of culture-bound terms. Bern/ Genève: ASTTI/ETI, 357-369.

[9] Newmark, P. (1988). Textbook of translation. Oxford: Pergamon Press.

[10]Yakhina, G. Zuleikha. Oneworld Publications, 2019. 